\title{
Bioactive's Characterization, Biological Activities, and In Silico Studies of Red Onion (Allium cepa L.) Skin Extracts
}

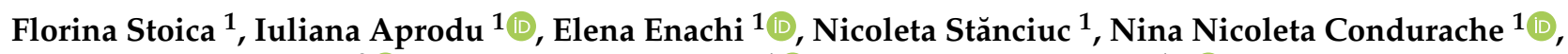 \\ Denisa Eglantina Duță ${ }^{2}$, Gabriela Elena Bahrim ${ }^{1}$ (I) and Gabriela Râpeanu ${ }^{1, *}$ (I) \\ 1 Faculty of Food Science and Engineering, Dunarea de Jos University of Galati, 111 Domneasca Street, \\ 800201 Galati, Romania; florina.stoica@ugal.ro (F.S.); iuliana.aprodu@ugal.ro (I.A.); \\ elena.ionita@ugal.ro (E.E.); nicoleta.stanciuc@ugal.ro (N.S.); nina.condurache@ugal.ro (N.N.C.); \\ gabriela.bahrim@ugal.ro (G.E.B.) \\ 2 National Institute of Research \& Development for Food Bioresources-IBA Bucharest, 6 Dinu Vintila Street, \\ 021102 Bucharest, Romania; denisa.duta@bioresurse.ro \\ * Correspondence: gabriela.rapeanu@ugal.ro; Tel.: +40-336-130177
}

check for

updates

Citation: Stoica, F.; Aprodu, I.; Enachi, E.; Stănciuc, N.; Condurache, N.N.; Duță, D.E.; Bahrim, G.E.; Râpeanu, G. Bioactive's

Characterization, Biological Activities, and In Silico Studies of Red Onion (Allium cepa L.) Skin Extracts. Plants 2021, 10, 2330. https://doi.org/ $10.3390 /$ plants10112330

Academic Editor: Enrico Doria

Received: 28 September 2021

Accepted: 26 October 2021

Published: 28 October 2021

Publisher's Note: MDPI stays neutral with regard to jurisdictional claims in published maps and institutional affiliations.

Copyright: (c) 2021 by the authors. Licensee MDPI, Basel, Switzerland. This article is an open access article distributed under the terms and conditions of the Creative Commons Attribution (CC BY) license (https:// creativecommons.org/licenses/by/ $4.0 /)$.

\begin{abstract}
This study aimed to investigate the thermal stability and biological activities of the phytochemicals from the red onion skins extract, which are a rich source of anthocyanins. Eight anthocyanins were identified in the extract by high-performance liquid chromatography, the most abundant ones being cyanidin 3-O-laminaribioside and cyanidin 3-O-(6"-malonoyl-laminaribioside). The study also involved the assessment of the thermal degradation kinetics of anthocyanins and antioxidant activity in the $75-155^{\circ} \mathrm{C}$ temperature range. The thermal degradation kinetics was described using the first-order kinetics model. In terms of thermal stability, increasing the temperature resulted in lower half-life values $\left(t_{1 / 2}\right)$ and higher degradation rate constant values $(k)$ for both anthocyanins and antioxidant activity. The thermodynamic parameters revealed that the phytochemicals degradation is a non-spontaneous and endothermic reaction. Furthermore, the inhibitory effect of the extract was investigated against the enzymes affiliated with metabolic syndrome, oxidative stress, and inflammatory process diseases. Thus, we also demonstrated that the red onion skins extract exerted inhibitory activity on $\alpha$-glucosidase, $\alpha$-amylase, lipase, and lipoxygenase. Considering the high content of bioactives and various biological properties, the red onion skins extract is suitable for multiple applications.
\end{abstract}

Keywords: red onion skins; anthocyanins; antioxidant activity; thermal stability; molecular modeling; biological activity

\section{Introduction}

The onions (Allium cepa L.) are among the world's oldest cultivated vegetables that are easily adaptable in a wide range of environments. The onion is used either fresh or processed, as an essential ingredient in many recipes, being accepted by almost all cultures [1]. Onions are important for both feeding and medicinal purposes. In the last years, the consumption of onion has expanded significantly due to its flavor and health benefits. These beneficial properties are related to the high content of organosulfur and phenolic compounds [2]. However, the onions' processing generates large quantities of wastes, mainly skins. For example, more than 500,000 tons of onion wastes are generated annually in the European Union and need useful management [3]. The onion wastes, particularly the non-edible dry skins, can be a potential source of bioactive compounds, mainly anthocyanins, and also can be processed and reused as bioactive food ingredients [4].

The red onion skins are rich in anthocyanins (cyanidin and peonidin derivatives) and flavonols (quercetin derivatives) [5]. The anthocyanins are a group of naturally occurring pigments derived from plant raw materials. They have remarkable importance due to their dual role: as an integral part with sensory attributes (color) and as compounds with 
health benefits and disease prevention effects [6]. The health-promoting effects are related to the antioxidant, anti-proliferative, anti-inflammatory, and cardioprotective activities, helping in regulating the lipid metabolism and improving insulin resistance [7]. Various studies [8-11] have shown that the red onion skins can exhibit inhibitory activity against the enzymes connected to metabolic syndrome and oxidative stress. Color is also a major attribute having a high influence on the appearance and the acceptance of food products.

The thermal treatment process is among the most widely used preservation methods to expand the food shelf-life and to ensure food safety [12]. Depending on the product attributes and intended shelf-life, food processing may include the thermal treatment in the $50-150{ }^{\circ} \mathrm{C}$ temperature range [13]. The anthocyanins are highly unsteady and susceptible to degradation by extrinsic factors such as temperature, $\mathrm{pH}$, oxygen, metal ions, light, enzymes, etc. [14]. Similarly, the phenolic compounds, as well as the antioxidant activity, can be degraded through heating. In this context, it can be predicted that industrial processing at different temperature-time combinations might cause changes in the levels of biologically active compounds. These changes lead to organoleptic and nutritional properties loss as well [13]. Due to their health benefits, there is a real need to preserve the content of anthocyanins, polyphenols, and antioxidant capacity in red onion skin extract. It is important as well to secure the optimal color and nutritional quality of food during thermal processing. Therefore, a precise understanding of the thermal degradation mechanisms based on mathematical models allows the optimization of industrial processing [15].

The purpose of the present study was to extract and characterize the anthocyanins found in the red onion skins. The thermostability, thermal degradation kinetics, and thermodynamic parameters associated with the total anthocyanins content (TAC) and antioxidant activity of the extract were investigated. Moreover, molecular modeling was used to simulate the thermal-dependent behavior of the main anthocyanin molecules from the onion skins. In addition, the biological activities of the extract were evaluated against $\alpha$-glucosidase, $\alpha$-amylase, pancreatin lipase, and lipoxygenase (LOX), enzymes associated with different diseases. Molecular docking tests were finally carried out to check the ability of the anthocyanins from the onion skins to recognize and interfere with the catalytic site of these enzymes.

\section{Results and Discussion}

\subsection{Extraction and Characterization}

The extraction was performed using the ultrasound-assisted extraction (UAE) method with aqueous ethanol 70\% acidified with glacial acetic acid (in a $6: 1$ ratio, $\%(v / v)$ ), and the red onion skins extract was characterized in terms of phytochemical content and antioxidant activity (Table 1). The anthocyanins are the compounds responsible for the $\mathrm{red} /$ purple color of red onion, are highly concentrated in the skins and the outer fleshy layers of red onion [16,17].

Table 1. The extract phytochemical characterization.

\begin{tabular}{cc}
\hline Selected Phytochemical & Extract \\
\hline TAC, mg C3G/g DW & $2.75 \pm 0.15$ \\
TPC, mg GAE/g DW & $172.17 \pm 3.01$ \\
Antioxidant activity, mM TE/g DW & $436.25 \pm 3.51$ \\
\hline
\end{tabular}

In our study, the extract presented an average TAC of $2.75 \pm 0.15 \mathrm{mg} \mathrm{C3G/g} \mathrm{DW.} \mathrm{Our}$ results are in agreement with other studies reported by Ali et al. [18], Katsampa et al. [19], Viera et al. [15], and Makris [20]. Ali et al. [18] reported $2.25 \mathrm{mg} \mathrm{C3G/g}$ red onion skins anthocyanins to extract prepared with $0.01 \% \mathrm{HCl}$ acidified ethanol. Katsampa et al. [19] found $2.09 \mathrm{mg} \mathrm{C} 3 \mathrm{G} / \mathrm{g}$ DW in the red onion skins extract obtained with the UAE method using $90 \%(w / v)$ aqueous glycerol as solvent. Viera et al. [15] reported a TAC of $227.7 \pm 16.2 \mathrm{mg}$ C3G/100 g DW using the conventional extraction method with aqueous ethanol $60 \%(v / v)$, 
after $30 \mathrm{~min}$ of extraction, while Makris [20] found a TAC of $183.85 \mathrm{mg}$ C3G/100 g after $3.7 \mathrm{~h}$ of extraction with aqueous ethanol $60 \%(v / v)$.

The total polyphenols content (TPC) of the red onion skins extract was $172.17 \pm 3.01 \mathrm{mg}$ GAE/g DW. This value is in line with the ones reported by Viera et al. [15] who reported $188.4 \pm 58.8 \mathrm{mg} \mathrm{GAE} / \mathrm{g}$ DW for the red onion skins to extract obtained with aqueous ethanol $40 \%(\mathrm{v} / \mathrm{v})$, after $60 \mathrm{~min}$ at $25^{\circ} \mathrm{C}$. Škerget et al. [21] reported a TPC of $114.86 \pm 1.15 \mathrm{mg} \mathrm{GAE} / \mathrm{g}$ of red onion skins to extract, after $5 \mathrm{~h}$ of extraction with aqueous ethanol $60 \%(v / v)$ at $25^{\circ} \mathrm{C}$. Higher values were reported by Yang et al. [22] who found a content of $233.40 \pm 0.58 \mathrm{mg} \mathrm{GAE} / \mathrm{g}$ of extract when using aqueous ethanol $70 \%(v / v)$ as a solvent, and Lee et al. [23] who acquired a TPC of $372.50 \pm 6.85 \mathrm{mg} \mathrm{GAE} / \mathrm{g}$ of extract obtained with aqueous ethanol $70 \%(v / v)$ at $60{ }^{\circ} \mathrm{C}$ for $3 \mathrm{~h}$ extraction.

The antioxidant activity of the red onion skins extract was determined by measuring the radical-scavenging activity on DPPH. After $30 \mathrm{~min}$ of reaction, the red onion skins extract showed antioxidant activity of $436.25 \pm 3.51 \mathrm{mM}$ TE/g DW. A similar antioxidant activity ( $490.54 \pm 9.43 \mathrm{mM} \mathrm{TE} / \mathrm{g} \mathrm{DW})$ for the ultrasounds treated red onion skins extract was determined by Prokopov et al. [24] using aqueous ethanol 70\% (v/v). Viera et al. [15] determined the antioxidant activity of the red onion skins extract obtained by conventional extraction, and the highest value of $100.1 \pm 4.9 \mu \mathrm{M}$ TE/g DW was obtained with aqueous ethanol $60 \%(v / v)$ after $240 \mathrm{~min}$ at $25^{\circ} \mathrm{C}$. All these authors reported variable results for the phytochemical content of the red onion skin extract due to the differences regarding the phytochemical variability in raw material, environment, and extraction conditions.

\subsection{Chromatographic Profile of the Anthocyanins from the Red Onion Skins Extract}

The anthocyanins from the red onion skins extract were separated and identified at $520 \mathrm{~nm}$ using the HPLC technique. The identification of the anthocyanins was achieved based on the retention time (RT) and by comparison to the available standards.

The HPLC-DAD profile of the red onion skins extracts revealed the presence of eight compounds: cyanidin 3-O-glucoside, cyanidin 3-O-laminaribioside, cyanidin 3$\mathrm{O}$-(3"-malonylglucoside), peonidin 3-O-glucoside, cyanidin 3-O-(6"-malonylglucoside), cyanidin 3-O-(6"-malonyl-laminaribioside), peonidin 3-O-malonylglucoside, and cyanidin 3-dimalonylaminaribioside (Figure 1). Two major compounds were found in the red onion skins extract: cyanidin 3-O-laminaribioside with a concentration of $29.95 \%$, and cyanidin 3-O-(6"-malonyl-laminaribioside) with a concentration of $38.93 \%$ of the total anthocyanins content. Peonidin 3-O-malonylglucoside, as the third major compound, constitutes $8.55 \%$ of the total anthocyanin content. Each of the other identified compounds contributed with a concentration lower than $8 \%$ of the total anthocyanins content. These observations comply with our previous study, in which the main anthocyanins found in the red onion skins extract were cyanidin 3-O-laminaribioside, cyanidin 3-O-(6"-malonyllaminaribioside), and peonidin 3-O-malonylglucoside [25]. In general, our results are in agreement with the literature data [26], the most commonly reported anthocyanins in the red onion being cyanidin derivatives. Also, in the literature, the acetylated anthocyanins with malonic acid are the predominant pigments identified in the red onion chromatographic profile [16]. Donner et al. [27] also identified cyanidin 3-O-laminaribioside and cyanidin 3-O-(6"-malonyl-laminaribioside) in different red onion extracts, but in their study cyanidin 3-O-(6" -malonylglucoside) and cyanidin 3-O-glucoside were the major ones. 


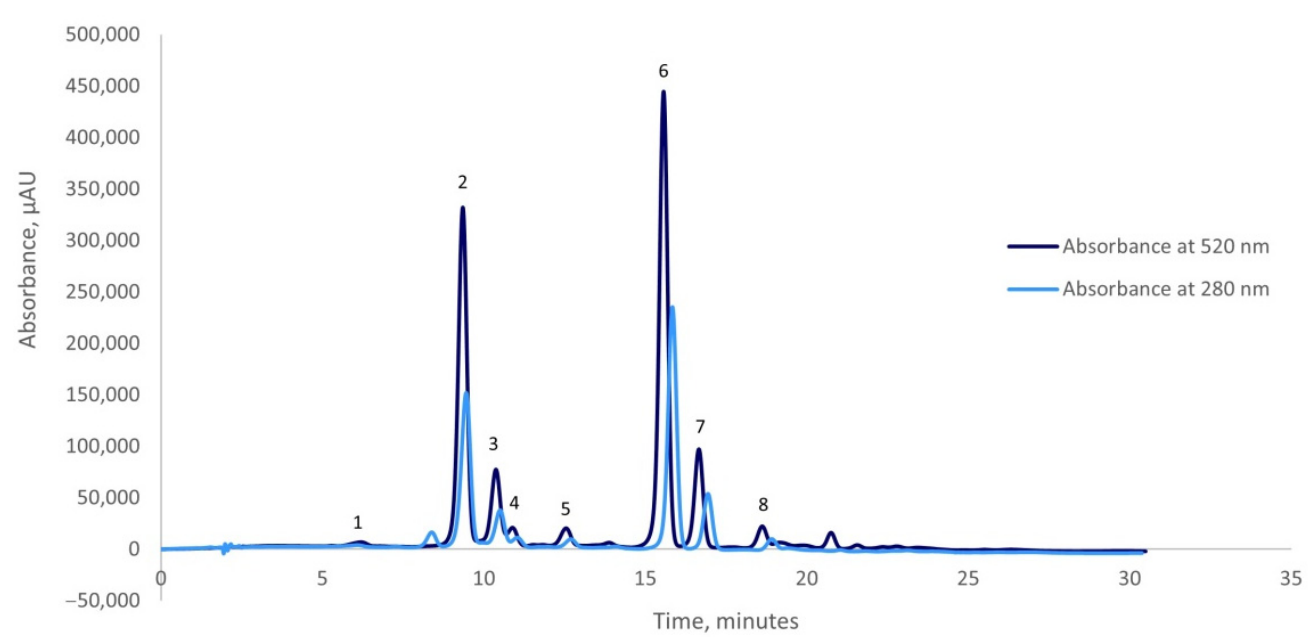

Figure 1. Chromatographic profile of the anthocyanins from the red onion skins extract obtained by ultrasounds-assisted extraction: Peak (1) cyanidin 3-O-glucoside; Peak (2) cyanidin 3O-laminaribioside; Peak (3) cyanidin 3-O-( $3^{\prime \prime}$-malonylglucoside); Peak (4) peonidin 3-O-glucoside; Peak (5) cyanidin 3-O-(6" -malonylglucoside); Peak (6) cyanidin 3-O-(6" -malonyl-laminaribioside); Peak (7) peonidin 3-O-malonylglucoside and Peak (8) cyanidin 3-dimalonylaminaribioside.

\subsection{Heat Treatment}

The heat treatment results showed that increasing the temperature in the $75-155{ }^{\circ} \mathrm{C}$ range influenced the TAC. The decrease of TAC was observed as time and temperature increased (Figure 2a). In this study, the thermal degradation of red onion skins anthocyanins followed the first-order reaction kinetics $\left(R^{2}>0.9\right)$. These results are similar to those reported by Turturică et al. [28,29] and Oancea et al. [30].

Our results showed that the beginning of the degradation process occurred slowly at $75^{\circ} \mathrm{C}$ and was more intense at $155^{\circ} \mathrm{C}$. Thus, the TAC in red onion skin extract presented a $7.60 \%$ decrease after $15 \mathrm{~min}$ of heating at $75^{\circ} \mathrm{C}$ and $99.25 \%$ after $60 \mathrm{~min}$ of thermal treatment at $155^{\circ} \mathrm{C}$. Similar results were obtained in other studies performed on other plant matrices. For example, Turturică et al. [29] reported a severe reduction of the TAC from sweet cherry skins to extract, between $47 \%$ and $63 \%$ after $60 \mathrm{~min}$ of heat treatment at temperatures ranging from $90{ }^{\circ} \mathrm{C}$ to $120^{\circ} \mathrm{C}$. Oancea et al. [30] also reported that, after $120 \mathrm{~min}$ of thermal treatment at temperatures of 100 and $150{ }^{\circ} \mathrm{C}$, the anthocyanins from sour cherry skins extract decreased by almost $42 \%$ and $96 \%$, respectively. In plums (Prunus domestica) skins extract, the TAC degradation percentage after $20 \mathrm{~min}$ of thermal treatment at $70{ }^{\circ} \mathrm{C}$ and $110{ }^{\circ} \mathrm{C}$ was $47 \%$ and $91 \%$, respectively [28].

The degradation was substantially slower at lower temperatures and faster at higher heating temperatures, indicating that time and temperature have a strong influence on anthocyanin stability, as expected [31]. The degradation of anthocyanins is mainly caused by oxidation, cleavage of covalent bonds, or enhanced oxidation reactions as a result of thermal processing. Probably during heat treatment, anthocyanins or their conjugated sugars are broken down into small molecules [31,32].

In the case of antioxidant activity, the first-order kinetic model was found to be the most suitable for representing the effect of thermal degradation (Figure 2). Figure $2 b$ shows that the antioxidant activity of the red onion skin extract decreased throughout the heating temperature and time. However, as expected, the degradation was less pronounced when lower temperatures were used. The decrease of the antioxidant activity of the extract heat-treated for $60 \mathrm{~min}$ in the temperature domain $75-115{ }^{\circ} \mathrm{C}$, ranged from $12.16 \%$ to $20.98 \%$. The degradation process intensified when higher temperatures were applied; the extract lost $30.09 \%$ of the initial antioxidant activity after $60 \mathrm{~min}$ of heat treatment at $155^{\circ} \mathrm{C}$. Therefore, it can be appreciated that the antioxidant potential of the extract was maintained throughout the studied temperature range. Over the same temperature range, the antioxidant activity exhibited a lower decrease compared to TAC. The thermal degradation trend 
is rather similar to other antioxidant compounds like phenolics (flavonoids), phenolic acids, alk(en)yl cystein sulphoxides that in term presented a much better thermostability [33].
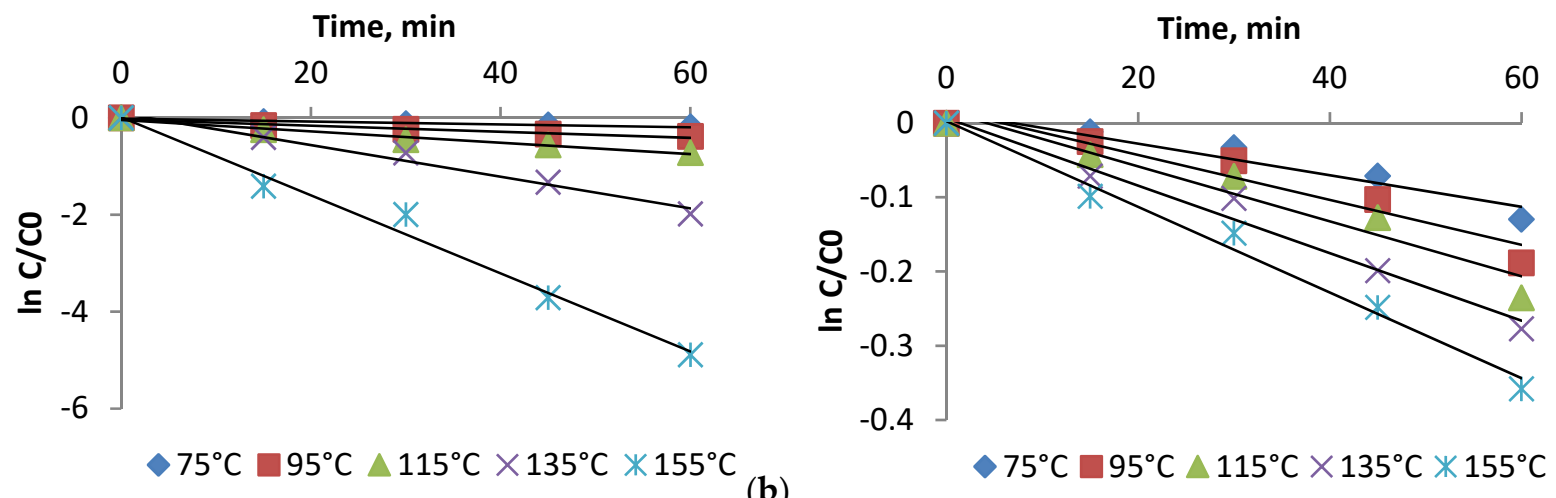

(a)

(b)

Figure 2. Thermal degradation kinetics of TAC (a) and antioxidant activity (b) of red onion skin extract that was treated at different temperatures $\left(* 75^{\circ} \mathrm{C}, \| 95^{\circ} \mathrm{C}, \Delta 115^{\circ} \mathrm{C}, \times 135^{\circ} \mathrm{C}, * 155^{\circ} \mathrm{C}\right) ; \mathrm{C}_{0}$ and $\mathrm{C}$ are the TAC or antioxidant activity before and after thermal treatment $(\mathrm{mg} / \mathrm{g} \mathrm{dw})$.

These results are in agreement with the results reported by Oancea et al. [30], and Turturică et al. [28,29]. Oancea et al. [30] found a decrease of $10-17 \%$ of the antioxidant activity of the sour cherry skins extract during the $60 \mathrm{~min}$ thermal treatment at $100-150{ }^{\circ} \mathrm{C}$. In sweet cherries skins extract, heating caused an antioxidant activity decrease between $22-27 \%$ in the temperature range of $50-100{ }^{\circ} \mathrm{C}$ after $15 \mathrm{~min}$. The decrease attained a maximum value of $44 \%$ after $60 \mathrm{~min}$ at $120{ }^{\circ} \mathrm{C}$ [29]. Turturică et al. [28] observed a reduction of the antioxidant activity of plums skins extract between $3-12 \%$ up to $5 \mathrm{~min}$ of heating at the temperature range of $70-90{ }^{\circ} \mathrm{C}$. The rate of the antioxidant activity loss gradually increased with increasing the heating time, reaching a maximum value of $61 \%$ after $20 \mathrm{~min}$ at $110^{\circ} \mathrm{C}$.

In general, the thermal degradation of anthocyanins begins with the hydrolysis of sugar moieties. A careful analysis of the anthocyanin molecules heated by the in silico approach at temperatures resembling the experimental ones showed that planarity of the aromatic rings in the anthocyanidins structure changed with the intensity of the thermal treatment. Equilibrating the anthocyanin models at increasing temperatures from 75 to $155^{\circ} \mathrm{C}$ resulted in more advanced tilting of the phenyl aromatic ring towards the benzopyrylium. Moreover, a slight increase of the $\mathrm{C}-\mathrm{O}-\mathrm{C}$ angle ensuring the connection between sugar and anthocyanidin was observed with the temperature; the $\mathrm{C}-\mathrm{O}-\mathrm{C}$ increased from $125.13^{\circ}$ (at $75{ }^{\circ} \mathrm{C}$ ) to $133.05^{\circ}$ (at $155^{\circ} \mathrm{C}$ ) for the cyanidin 3-O-laminaribioside, and from $125.66^{\circ}$ (at $75^{\circ} \mathrm{C}$ ) to $128.61^{\circ}$ (at $155^{\circ} \mathrm{C}$ ) in case of cyanidin 3-O-( $6^{\prime \prime}$-malonyl-laminaribioside). In addition, the $8.5 \%$ stretching of the bonds involved in defining this angle supports the hypothesis of potential anthocyanins deglycosylation at high temperatures. The deglycosylation of anthocyanins results in the formation of anthocyanidins, which are further degraded in chalcones. The breakdown of chalcones generates the formation of phenolic acids and carboxaldehyde [34]. It has been supposed that the degradation products of anthocyanins display antioxidant properties [35]. Moreover, Sui and Zhou [36] showed negligible losses in the antioxidant capacity of aqueous solutions of anthocyanins after thermal treatment at a temperature range of $100-165^{\circ} \mathrm{C}$. The formation of other phenolic compounds by the anthocyanins' degradation was suggested to be the reason for the nearly constant antioxidant capacity observed in the aqueous solutions. 


\subsection{Estimation of TAC and Antioxidant Activity Degradation Kinetic Parameters}

The degradation of TAC and antioxidant activity of the red onion skins extract was further studied by analyzing the kinetic parameters. Table 2 presents the kinetic parameters: the kinetic rate constants $(\mathrm{k})$, the half-life values $\left(\mathrm{t}_{1 / 2}\right)$, D parameter values, $\mathrm{z}$-values, and activation energy $(\mathrm{Ea})$ values.

The kinetic rate constant allows the prediction of the TAC's thermal degradation. The lower the $\mathrm{k}$ value, the higher the TAC stability. In our study, the $\mathrm{k}$ values ranged from $(0.69 \pm 0.08) \times 10^{-2} \mathrm{~min}^{-1}$ at $75^{\circ} \mathrm{C}$ to $(18.65 \pm 2.36) \times 10^{-2} \mathrm{~min}^{-1}$ at $155^{\circ} \mathrm{C}$. It is clear from Table 2 that as the temperature increased, the $\mathrm{k}$ values also increased, indicating that a higher degradation occurred at higher processing temperatures. This finding points out that temperature strongly affects the stability of anthocyanins. Al-Qadri [37] analyzed the kinetic parameters of anthocyanins degradation in red onion skins extracts at different temperatures. The thermal degradation rate constants showed values of $66 \times 10^{-2} \mathrm{~h}^{-1}$ at $100{ }^{\circ} \mathrm{C}, 25 \times 10^{-2} \mathrm{~h}^{-1}$ at $70^{\circ} \mathrm{C}$, and $8.3 \times 10^{-2} \mathrm{~h}^{-1}$ at $50{ }^{\circ} \mathrm{C}$. Turturică et al. [29] reported $\mathrm{k}$ values ranging from $(9.00 \pm 2.58) \times 10^{-2} \mathrm{~min}^{-1}$ at $70^{\circ} \mathrm{C}$ to $(10.87 \pm 1.57) \times 10^{-2} \mathrm{~min}^{-1}$ at $120^{\circ} \mathrm{C}$ for TAC thermal degradation in sweet cherry skins extract. Oancea et al. [30] studied the TAC kinetics degradation during the heat treatment of sour cherries skins extract and reported the increase of the degradation constant rate with increasing temperature.

The $\mathrm{D}$ values decreased with increasing temperature, showing clear differences in the thermal sensitivity at different temperatures. At $75^{\circ} \mathrm{C}$, the D value was $333.33 \pm 6.85 \mathrm{~min}$, while a decrease of approximately $96.3 \%$ was observed by increasing the temperature to $155^{\circ} \mathrm{C}$.

The $\mathrm{z}$ parameter expresses the increase in temperature required to reduce $\mathrm{D}$ by $10 \%$. The z-value reported in Table 2 asserts that the thermal resistance factors for several food characteristics, such as the color given by the targeted bioactives, are greater than the value needed for the spores or vegetative cells $\left(z=5-12{ }^{\circ} \mathrm{C}\right)$. Hence, the rates of the degradation of the color are much less temperature-sensitive [38]. Nayak et al. [39] reported a z-value of $47.9^{\circ} \mathrm{C}$ for the purple potatoes anthocyanins' degradation while the D parameter varied between 87.9-8.1 min after heat treatment in the temperature range of $100-150^{\circ} \mathrm{C}$. Peron et al. [12] studied the degradation of anthocyanins from grape and juçara extracts between 50 and $90{ }^{\circ} \mathrm{C}$ and suggested z-values of $23.2{ }^{\circ} \mathrm{C}$ in juçara extract and $24.4^{\circ} \mathrm{C}$ in the "Italia" grape extract. Also, they reported D values between $1715-31 \mathrm{~h}$, and $312-7 \mathrm{~h}$ respectively.

Another way to express the degradation of TAC is by using the $t_{1 / 2}$ values. As shown in Table 2, it was noticed that as the temperature increased, the $t_{1 / 2}$ values decreased consistently with faster reactions accompanied by higher $\mathrm{k}$ values. This trend is in good agreement with other studies from the literature [30,37,39]. Al-Qadri [37] previously reported that $\mathrm{t}_{1 / 2}$ values of anthocyanins in a red onion skins extract were $83.49 \mathrm{~h}$ at $50^{\circ} \mathrm{C}$ and $10.5 \mathrm{~h}$ at $100{ }^{\circ} \mathrm{C}$. Oancea et al. [30] studied the kinetics of anthocyanins thermal degradation in sour cherries skins extract in the temperature range of $100-160{ }^{\circ} \mathrm{C}$ for different heating periods and pointed out the high thermostability of anthocyanins. They reported the $\mathrm{t}_{1 / 2}$ ranging from $158.40 \pm 5.77 \mathrm{~min}$ at $100{ }^{\circ} \mathrm{C}$ to $11.44 \pm 0.54 \mathrm{~min}$ at $160{ }^{\circ} \mathrm{C}$. Lower $\mathrm{t}_{1 / 2}$ values of $26.45 \mathrm{~min}$ at $100{ }^{\circ} \mathrm{C}$ and $2.42 \mathrm{~min}$ at $150{ }^{\circ} \mathrm{C}$ were registered by Nayak et al. [39], when characterizing the anthocyanins from the purple potato extract.

In general, the activation energy $(\mathrm{Ea})$ is used to characterize the energy needed to reach the active state of a reaction [40]. The Ea for TAC degradation was calculated as $50.77 \pm 1.71 \mathrm{~kJ} \cdot \mathrm{mol}^{-1}$. The Ea was similar to the one determined by Oancea et al. [30] for the sour cherries skins anthocyanins (Ea of $54.19 \pm 5.88 \mathrm{~kJ} \mathrm{~mol}^{-1}$ ). In the study conducted by Al-Qadri [37], Ea values of $39.10(\mathrm{~kJ} / \mathrm{mol})$ were reported after the thermal treatment of red onion skin extract. Turturică et al. [28] found a Ea of $36.42 \pm 2.89 \mathrm{~kJ} \mathrm{~mol}^{-1}$ for the thermal degradation of anthocyanins in the plum skins extract. 
Table 2. The degradation kinetic parameters (degradation rate constant $-k$, correlation coefficient $R^{2}$, decimal reduction time- $D$, $z$-value, activation energy-Ea, and half-life values- $t_{1 / 2}$ ) of the total anthocyanins content (TAC) and antioxidant activity from the red onion skins extract heat-treated at different temperatures.

\begin{tabular}{|c|c|c|c|c|c|}
\hline Compounds & Temperature ${ }^{\circ} \mathrm{C}$ & $\begin{array}{l}\mathrm{k} \cdot 10^{-2} \\
\left(\min ^{-1}\right)\end{array}$ & $\mathbf{R}^{2}$ & $t_{1 / 2}(\min )$ & $\mathrm{D}$ (min) \\
\hline \multirow{6}{*}{ TAC } & 75 & $0.69 \pm 0.08$ & 0.96 & $100.32 \pm 1.91$ & $333.33 \pm 6.85$ \\
\hline & 95 & $1.38 \pm 0.21$ & 0.96 & $50.16 \pm 1.42$ & $166.67 \pm 4.68$ \\
\hline & 115 & $2.53 \pm 0.83$ & 0.98 & $27.36 \pm 0.93$ & $90.91 \pm 3.45$ \\
\hline & 135 & $7.37 \pm 1.33$ & 0,98 & $9.41 \pm 0.72$ & $31.25 \pm 2.06$ \\
\hline & 155 & $18.65 \pm 2.36$ & 0.98 & $3.72 \pm 0.48$ & $12.35 \pm 1.08$ \\
\hline & \multicolumn{5}{|c|}{$\begin{array}{c}\mathrm{Ea}\left(\mathrm{kJ} \cdot \mathrm{mol}^{-1}\right)=50.77 \pm 1.71\left(\mathrm{R}^{2}=0.97\right) \\
\mathrm{Z}\left({ }^{\circ} \mathrm{C}\right)=55.56 \pm 2.91\left(\mathrm{R}^{2}=0.98\right)\end{array}$} \\
\hline \multirow{6}{*}{$\begin{array}{l}\text { Antioxidant } \\
\text { activity }\end{array}$} & 75 & $0.48 \pm 0.27$ & 0.92 & $143.32 \pm 2.42$ & $\begin{array}{c}476.19 \pm \\
10.31\end{array}$ \\
\hline & 95 & $0.69 \pm 0.42$ & 0.93 & $100.33 \pm 2.51$ & $333.33 \pm 9.57$ \\
\hline & 115 & $0.85 \pm 0.64$ & 0.93 & $81.34 \pm 1.82$ & $270.27 \pm 8.67$ \\
\hline & 135 & $1.04 \pm 0.75$ & 0.98 & $66.88 \pm 1.74$ & $222.22 \pm 7.48$ \\
\hline & 155 & $1.33 \pm 0.84$ & 0.99 & $51.89 \pm 1.46$ & $172.41 \pm 6.12$ \\
\hline & \multicolumn{5}{|c|}{$\begin{array}{c}\text { Ea }\left(\mathrm{kJ} \cdot \mathrm{mol}^{-1}\right)=15.13 \pm 2.05\left(\mathrm{R}^{2}=0.99\right) \\
\mathrm{Z}\left({ }^{\circ} \mathrm{C}\right)=188.68 \pm 5.11\left(\mathrm{R}^{2}=0.98\right)\end{array}$} \\
\hline
\end{tabular}

The kinetics data of the antioxidant activity degradation from red onion skin extract during heating were shown in Table 2. The $\mathrm{k}$ values increased from $(0.48 \pm 0.27)$ to $(1.33 \pm 0.84) \times 10^{-2} \mathrm{~min}^{-1}$ as the temperature increased. This trend indicates that the antioxidant activity rate of degradation varied with the temperature. Similarly, Turturi ă et al. [28] stated that the k values for the antioxidant activity thermal degradation in plums skin extract increased with increasing the temperature. Significantly higher $\mathrm{k}$ values were found in sweet cherries skins extract, ranging from $(9.27 \pm 1.76) \times 10^{-2} \mathrm{~min}^{-1}$ at $70{ }^{\circ} \mathrm{C}$ to $(10.65 \pm 2.83) \times 10^{-2} \mathrm{~min}^{-1}$ at $110^{\circ} \mathrm{C}$ accordingly to Turturică et al. [29]. Lower degradation rates, ranging from $(0.09 \pm 0.01) \times 10^{-2} \mathrm{~min}^{-1}$ at $100{ }^{\circ} \mathrm{C}$ to $(8.12 \pm 1.48) \times 10^{-2} \mathrm{~min}^{-1}$ at $160^{\circ} \mathrm{C}$, were observed by Oancea et al. [30] in sour cherries skins extract.

The $t_{1 / 2}$ of the antioxidant activity thermal degradation in red onion skins extract was $143.32 \pm 2.42 \mathrm{~min}$ at $75{ }^{\circ} \mathrm{C}$ but decreased to $51.89 \pm 1.46 \mathrm{~min}$ at $155^{\circ} \mathrm{C}$ (Table 2). The results showed that the DPPH radical scavenging activity of the red onion skins extract was more stable at low-temperature treatment. In accordance, Turturică et al. [28] reported that the antioxidant activity thermal degradation of plum extracts also followed the first-order reaction and the $t_{1 / 2}$ decreased from 173.28 to $33.00 \mathrm{~min}$ when the temperature increased from 70 to $110^{\circ} \mathrm{C}$. Lower $t_{1 / 2}$ values were found in sweet cherries skins extract, ranging from $7.47 \pm 0.71$ at $70{ }^{\circ} \mathrm{C}$ to $6.50 \pm 0.43 \mathrm{~min}$ at $110^{\circ} \mathrm{C}$ [29].

The Ea for the degradation of the antioxidant activity within the temperature domain considered in the study was $15.13 \pm 2.05 \mathrm{~kJ} / \mathrm{mol}$ (Table 2). The low value of Ea means that the antioxidant activity of the red onion skin extract is less sensitive to temperature change. Turturică et al. [28] reported an Ea value of $47.22 \pm 5.78 \mathrm{~kJ} \cdot \mathrm{mol}^{-1}$ for the skins of the plums to extract, while in another study [29], they reported an Ea value of $8.56 \pm 1.42 \mathrm{~kJ} \cdot \mathrm{mol}^{-1}$ for the sweet cherries skins to extract.

\subsection{Thermodynamic Parameters Calculation}

To evaluate if the kinetic model used in this study is thermodynamically possible, the estimation of the thermodynamic parameters was performed. The physical and chemical phenomena of TAC and antioxidant activity degradation were determined through thermodynamic studies. Knowing the thermodynamic parameters allows a deeper understanding of the thermal degradation kinetics, to minimize the undesired degradation 
processes and optimize the quality of the food products [12]. Table 3 presents the activation enthalpy $(\Delta H)$, the Gibbs free energy $(\Delta G)$, and the activation entropy $(\Delta S)$ at $75,95,115$, 135 , and $155^{\circ} \mathrm{C}$.

Table 3. Thermodynamic parameters $(\Delta \mathrm{H}, \Delta \mathrm{G}$, and $\Delta \mathrm{S})$ of phytochemical degradation process in red onion skins extract.

\begin{tabular}{ccccc}
\hline Compounds & $\begin{array}{c}\text { Temperature } \\
\mathbf{( K )}\end{array}$ & $\begin{array}{c}\Delta \mathbf{H} \\
\mathbf{( k J / m o l )}\end{array}$ & $\begin{array}{c}\Delta \mathbf{G} \\
\mathbf{( k J / m o l )}\end{array}$ & $\Delta \mathbf{S}(\mathbf{J} / \mathbf{( m o l} \cdot \mathbf{K}))$ \\
\hline & 348 & $47.88 \pm 0.62$ & $111.91 \pm 1.37$ & $-184.02 \pm 2.18$ \\
TAC & 368 & $47.71 \pm 0.28$ & $116.40 \pm 1.32$ & $-186.65 \pm 2.15$ \\
& 388 & $47.54 \pm 0.30$ & $120.94 \pm 3.49$ & $-189.16 \pm 1.43$ \\
& 408 & $47.38 \pm 0.34$ & $123.72 \pm 2.14$ & $-187.12 \pm 1.33$ \\
& 428 & $47.21 \pm 0.27$ & $126.65 \pm 2.18$ & $-185.61 \pm 1.56$ \\
\hline \multirow{2}{*}{ Antioxidant activity } & 348 & $12.24 \pm 0.16$ & $112.95 \pm 3.53$ & $-289.39 \pm 1.41$ \\
& 368 & $12.07 \pm 0.23$ & $118.52 \pm 1.41$ & $-289.25 \pm 0.92$ \\
& 388 & $11.91 \pm 0.15$ & $124.45 \pm 2.83$ & $-290.07 \pm 0.71$ \\
& 408 & $11.74 \pm 0.28$ & $130.37 \pm 2.57$ & $-290.77 \pm 0.87$ \\
& 428 & $11.57 \pm 0.40$ & $136.03 \pm 2.12$ & $-290.79 \pm 1.06$ \\
\hline
\end{tabular}

The activation enthalpy $(\Delta \mathrm{H})$ is defined as a measure of the energy barrier that must be overcome by the reacting molecules. Moreover, it is associated with the bonds which are broken and reformed during the intermediate states resulting from the reactants [41,42]. The $\Delta \mathrm{H}$ values of TAC ranged from $47.88 \pm 0.62$ to $47.21 \pm 0.27 \mathrm{~kJ} / \mathrm{mol}$. The $\Delta \mathrm{H}$ values of antioxidant activity ranged from $12.24 \pm 0.16$ to $11.57 \pm 0.40 \mathrm{~kJ} / \mathrm{mol}$. The positive values reveal that the bioactives' degradation was an endothermic reaction and prove that red onion skins' phytochemicals degraded with increasing temperature.

The Gibbs free energy $(\Delta \mathrm{G})$ describes the equilibrium and spontaneity of the activated state and reactants [43]. The $\Delta \mathrm{G}$ calculated for the TAC and antioxidant activity of red onion skins extract showed values ranging from $111.91 \pm 1.37$ to $126.65 \pm 2.18 \mathrm{~kJ} / \mathrm{mol}$ and $112.95 \pm 3.53$ to $136.03 \pm 2.12 \mathrm{~kJ} / \mathrm{mol}$, respectively. From Table 3 , it can also be seen that the $\Delta \mathrm{G}$ values increased with the temperature due to the high degradation rate of TAC and antioxidant activity at higher temperatures. The positive values of $\Delta \mathrm{G}$ indicate that the phytochemicals thermal degradation was a nonspontaneous reaction $[41,44]$.

The activation entropy $(\Delta S)$ is defined as the disorder degree of molecules in the system and is usually related to the number of molecules with appropriate energy to react [12]. The $\Delta S$ values calculated in this study were all negative, varying from -184.02 \pm 2.18 to $-185.61 \pm 1.56 \mathrm{~J} /(\mathrm{mol} \cdot \mathrm{K})$ for the TAC, and from $-289.39 \pm 1.41$ to -290.79 $\pm 1.06 \mathrm{~J} /(\mathrm{mol} \cdot \mathrm{K})$ for the antioxidant activity. These values indicate that there might be lesser structural freedom of the intermediate state (complex) compared to the reactant, resulting in the presence of an entropy barrier in the system. Also, it confirms that thermal degradation is an irreversible process.

Not many studies present the values of thermodynamic parameters, even though these parameters are important in estimating the mechanism of thermal degradation. AlQadri [37] reported a decrease in the values of entropy and enthalpy with the increase of the free energy for the red onion skin extracts thermally treated in the $40-100{ }^{\circ} \mathrm{C}$ temperature range. Moreover, Turturică et al. [29] estimated the thermodynamic parameters at different temperatures $\left(70-120^{\circ} \mathrm{C}\right)$ for the thermal degradation of anthocyanins in sweet cherries skins extract. They also reported an increase in the $\Delta \mathrm{G}$ and $\Delta \mathrm{H}$ values over the temperature range.

\subsection{In Vitro Enzyme Activity Inhibition}

The anthocyanins are phytochemicals of particular interest because of their potential health benefits [45]. The latter refers also to the benefits against metabolic syndrome (MetS) associated diseases. MetS is a clustering disorder comprising obesity, abnormal insulin and glucose metabolism, hypertension, disturbed blood lipids, pro-inflammatory state, and dyslipidemia [46]. Different enzymes like $\alpha$-glucosidase, $\alpha$-amylase, lipase, and LOX are involved in the appearance of these metabolic alterations. The most common clinical 
treatment in the management of MetS involves the prescription of enzyme inhibitors, such as acarbose for $\alpha$-glucosidase and $\alpha$-amylase, and orlistat for pancreatic lipase. However, the continuous intake of these drugs can cause adverse effects $[47,48]$. Thus, natural alternatives with fewer secondary effects are being currently studied.

The in vitro inhibitory effects of the red onion skins extract was assessed towards the enzymes associated with MetS: $\alpha$-glucosidase, $\alpha$-amylase, pancreatic lipase, and LOX. The inhibitory activity exerted by the biologically active compounds from the red onion skins was tested using three extract concentrations, namely $0.5,1$, and $5 \mu \mathrm{g} / \mathrm{mL}$. Acarbose, orlistat, and quercetin were used as positive controls. The results were expressed as $\mathrm{IC}_{50}$ values (Table 4 ).

Table 4. The enzyme inhibition capacity ( $\mathrm{IC}_{50}$ values; $\mu \mathrm{g} / \mathrm{mL}$ ) of red onion skins extract in $\alpha$-amylase, $\alpha$-glucosidase, lipase, and LOX enzymes.

\begin{tabular}{ccccc}
\hline Sample & \multicolumn{4}{c}{ IC $_{\mathbf{5 0}}(\mu \mathrm{g} / \mathbf{m L}$ Extract) } \\
\hline & $\alpha$-Amylase & $\alpha$-Glucosidase & Lipase & LOX \\
\hline Extract & $1.02 \pm 0.30 \mathrm{a}$ & $0.57 \pm 0.16 \mathrm{a}$ & $4.57 \pm 0.86 \mathrm{a}$ & $2.40 \pm 0.71 \mathrm{a}$ \\
Acarbose & $4.49 \pm 0.44 \mathrm{~b}$ & $2.09 \pm 0.14 \mathrm{~b}$ & - & - \\
Orlistat & - & - & $3.18 \pm 0.33 \mathrm{a}$ & - \\
Quercetin & - & - & - & $1.95 \pm 0.20 \mathrm{a}$ \\
\hline
\end{tabular}

Measurements are expressed as mean \pm SD of triplicates. Values (mean \pm SD) from a column that shares the same letter are not significantly different $(p>0.05)$.

The red onion skins extract was active against $\alpha$-amylase and $\alpha$-glucosidase with $\mathrm{IC}_{50}$ values of $0.57 \pm 0.16 \mu \mathrm{g} / \mathrm{mL}$ of extract for $\alpha$-glucosidase, and $1.02 \pm 0.30 \mu \mathrm{g} / \mathrm{mL}$ of extract for $\alpha$-amylase. The $\mathrm{IC}_{50}$ value registered in the case of acarbose was $2.09 \pm 0.14 \mu \mathrm{g} / \mathrm{mL}$ for $\alpha$-glucosidase and $4.49 \pm 0.44 \mu \mathrm{g} / \mathrm{mL}$ for $\alpha$-amylase. Acarbose showed a greater inhibitory effect towards $\alpha$-glucosidase than $\alpha$-amylase, the $\mathrm{IC}_{50}$ value obtained for $\alpha$-glucosidase being 2 times lower than that of $\alpha$-amylase. As shown in Table 4 , the tested extract was more active towards $\alpha$-glucosidase and $\alpha$-amylase than the reference compound.

In other studies, Nile et al. [49] found that red onion solid waste extract exhibited good $\alpha$-glucosidase inhibitory activity, with an $\mathrm{IC}_{50}$ of $48.6 \pm 1.8 \mu \mathrm{g} / \mathrm{mL}$, and with an $\mathrm{IC}_{50}$ of $10.1 \pm 0.6, \mu \mathrm{g} / \mathrm{mL}$ for acarbose. $\mathrm{IC}_{50}$ values of $52.5 \pm 1.1 \mu \mathrm{g} / \mathrm{mL}$ for $\alpha$-amylase and $55.2 \pm 1.3 \mu \mathrm{g} / \mathrm{mL}$ for $\alpha$-glucosidase were reported for the yellow onion solid waste extract. Also, $\mathrm{IC}_{50}$ of $50.5 \pm 1.2 \mu \mathrm{g} / \mathrm{mL}$ for $\alpha$-amylase and $80.3 \pm 1.7 \mu \mathrm{g} / \mathrm{mL}$ for $\alpha-$ glucosidase were reported for the positive control, acarbose [50]. Our results are higher than those of Oboh et al. [51] who reported that the aqueous extract of the purple onion exhibited weak inhibition on $\alpha$-amylase ( $\mathrm{IC}_{50}$ of $8.27 \mathrm{mg} / \mathrm{mL}$ ), and $\alpha$-glucosidase $\left(\mathrm{IC}_{50}\right.$ of $4.50 \mathrm{mg} / \mathrm{mL})$, respectively.

Kim et al. [52] investigated the in vitro inhibitory activity of the onion skins extract (Korean onion variety) against $\alpha$-glucosidase and $\alpha$-amylase. The extract presented $\mathrm{IC}_{50}$ values of $1.27 \mathrm{mg} / \mathrm{mL}$ for $\alpha$-glucosidase, and higher than $3.00 \mathrm{mg} / \mathrm{mL}$ for $\alpha$-amylase. Nickavar and Yousefian [53] reported the $\alpha$-amylase inhibitory potential of a common onion A. cepa L. variety, which showed $\mathrm{IC}_{50}$ values of $16.36 \mathrm{mg} / \mathrm{mL}$. The $\mathrm{IC}_{50}$ value of acarbose measured was $0.028 \mu \mathrm{g} / \mathrm{mL}$. These results suggest that the red onion skins extract and its constituents may serve as a potential source of natural $\alpha$-amylase and $\alpha$-glucosidase inhibitors. The ability of the red onion skin extract to inhibit $\alpha$-amylase and $\alpha$-glucosidase can be credited to the numerous phytochemicals constituent present in the dry skins of the red onion such as flavonols $[17,54]$ and anthocyanins $[17,55]$, which have been shown to exhibit enzyme inhibitory activity.

In order to find alternative natural sources for obesity treatment, we evaluated the effect of the red onion skin extract on lipase activity (Table 4). The extract showed an $\mathrm{IC}_{50}$ value of $4.57 \pm 0.86 \mu \mathrm{g} / \mathrm{mL}$ against the pancreatic lipase, while the orlistat presented an $\mathrm{IC}_{50}$ value of $3.18 \pm 0.33 \mu \mathrm{g} / \mathrm{mL}$. The $\mathrm{IC}_{50}$ value of the red onion skins extract was statistically similar to the standard inhibitor. Kim et al. [10] assessed the effects of onion (Allium cepa) 
skins extract on pancreatic lipase. The tested concentration $(455 \mu \mathrm{g} / \mathrm{mL})$ of the extract inhibited the pancreatic lipase, thus obtaining an $\mathrm{IC}_{50}$ value of $53.70 \mu \mathrm{g} / \mathrm{mL}$, while the orlistat presented an $\mathrm{IC}_{50}$ value of $0.04 \mu \mathrm{g} / \mathrm{mL}$. More recently, the lipase inhibitory potential of the yellow onion juice was also tested by Trisat et al. [56]. The sample inhibited the pancreatic lipase with an $\mathrm{IC}_{50}$ value of $9.5 \pm 21.1 \mathrm{mg} / \mathrm{mL}$. The pancreatic lipase inhibitory activity of the extract indicates a potential reduction of the digestion and absorption of dietary lipids.

The effect of the red onion skins extract was also measured against the proinflammatory enzyme LOX (Table 4). The $\mathrm{IC}_{50}$ value of the extract for LOX was $2.40 \pm 0.71 \mu \mathrm{g} / \mathrm{mL}$, while the positive control-quercetin, presented an $\mathrm{IC}_{50}$ value of $1.95 \pm 0.20 \mu \mathrm{g} / \mathrm{mL}$. According to the results obtained, the red onion skins extract possesses slightly lower LOX inhibitory activity compared to the standard used. In a study by Lesjak et al. [11] a common variety of yellow onion extract exhibited lower anti-inflammatory potential than the pure compound, but with a high $\mathrm{IC}_{50}$ value (100 $\mu \mathrm{g} / \mathrm{mL}$ ), suggesting the presence of active principles. Also, quercetin-3,4'-O-di-glucoside and quercetin aglycone exhibited high inhibitory potential towards LOX. Therefore, the authors concluded that these two compounds may contribute to the anti-inflammatory activity of $A$. серa L. extract. Hence, the red onion skins extract was able to inhibit the LOX. These findings, together with the antioxidant activity observed in the extract may contribute to the reduction of inflammation.

Molecular docking tests were further employed to check if any of the two major anthocyanins identified in the red onion skins extract through HPLC directly binds to the active site of these enzymes, in such a manner to interfere with substrate recognition or its transformation. The in-depth analysis of the three top-scoring complexes showed that cyanidin 3-O-laminaribioside and/or cyanidin 3-O-(6"-malonyl-laminaribioside) might contribute to the inhibition of the activity of $\alpha$-amylase, $\alpha$-glucosidase, lipase, and LOX (Figure 3), therefore explaining the experimental findings presented in Table 4.

The activity of $\alpha$-amylase appears to be potentially affected by the presence of cyanidin 3-O-(6"-malonyl-laminaribioside) which has a good affinity towards the active site of the enzyme, establishing contacts with the catalytic amino acids Asp ${ }^{197}$, Asp ${ }^{300,}$ and $\mathrm{Glu}^{233}$ [57]. The best fit predicted for the $\alpha$-glucosidase-cyanidin 3-O-laminaribioside complex involves the direct contact of the ligand with the catalytic acid Asp ${ }^{616}$ [58]. In the case of lipase, both investigated ligands appear to be able to attach to the enzyme surface, near the hydrogen-bonded triad formed Ser ${ }^{152}$, Asp ${ }^{176,}$ and His ${ }^{263}$ [59]. Regarding LOX, both investigated ligands bind in the vicinity of $\mathrm{Phe}^{177}$ and $\mathrm{Tyr}^{181}$ located at one end of the active site cavity [60], being therefore potentially responsible for limiting the access of the substrate to the channel leading to the catalytic iron. Ligands binding near the active site of the four investigated enzymes might induce substantial local conformational changes, therefore, explaining the results of the experimental tests. 


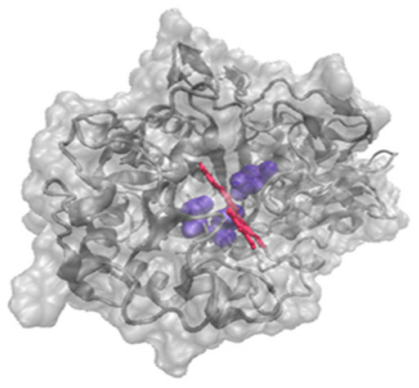

(a)

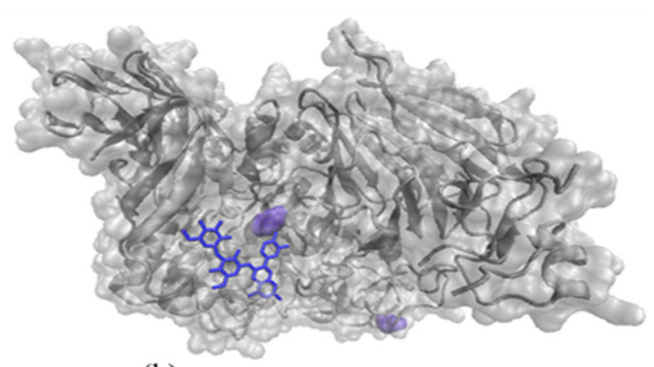

(b)
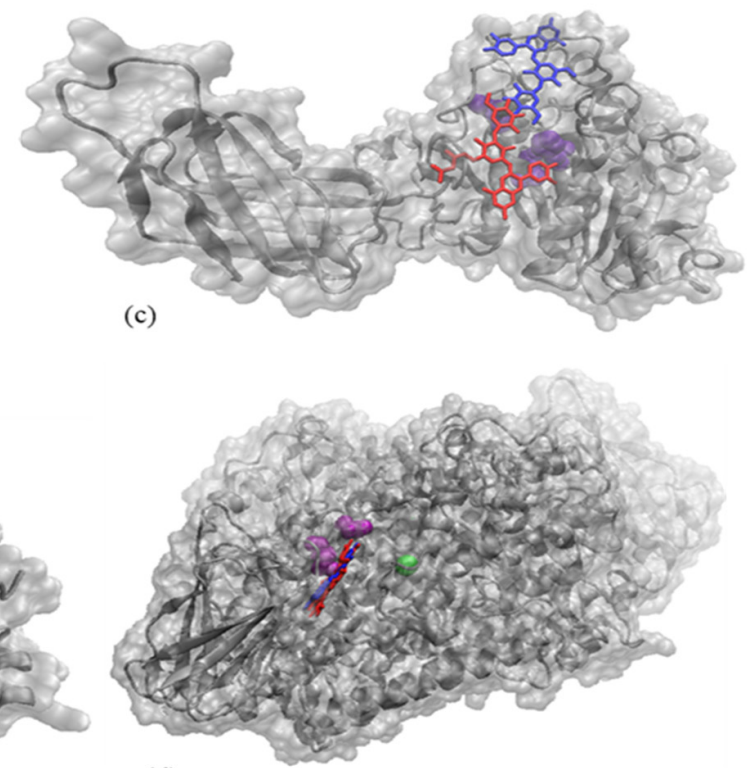

(d)

Figure 3. The results of the molecular docking tests showing the complexes formed by $\alpha$-amylase (a) $\alpha$-glucosidase (b), lipase (c), and LOX (d) shown in silver, with cyanidin 3-O-laminaribioside and/or cyanidin 3-O-(6"-malonyl-laminaribioside) represented in Licorice style in blue and red, respectively. The catalytic amino acids establishing contacts with the ligands are represented in purple in Van der Waals style. Images were prepared using VMD software [61].

\section{Materials and Methods}

\subsection{Materials}

The red onion (Allium cepa L.) was purchased from a local marketplace (Galati, Romania) in July 2020. The skins were manually detached, washed with distilled water, and dried at $40{ }^{\circ} \mathrm{C}$ for $2 \mathrm{~h}$ in an oven (Stericell 111, MMM Medcenter, München, Germany) up to moisture content (MF-50 moisture analyzer, A\&D Company, Tokyo, Japan) of 11.0\%. The dried skins were then ground with a domestic grinder and stored in a hermetically sealed container at $4{ }^{\circ} \mathrm{C}$ until further analysis.

\subsection{Chemicals}

Gallic acid, 2,2-diphenyl-1-picrylhydrazyl (DPPH), methanol (HPLC grade), 6hydroxy-2,5,7,8-tetramethylchromane-2-carboxylic acid (Trolox), sodium acetate solution, potassium chloride solution, $\alpha$-glucosidase from Saccharomyces cerevisiae ( $\geq 10 \mathrm{units} / \mathrm{mg}$ protein), lipoxygenase from Glycine max (soybean) type I-B, 50,000 units/mg protein, $\alpha$ amylase from porcine pancreas (type I-A, 700-1400 units/mg protein), pancreatin lipase (111.5 units/mg protein), linoleic acid ( $\geq 99 \%)$, p-nitrophenyl- $\alpha$-D-glucopyranoside ( $\geq 97.5 \%)$, p-nitrophenyl palmitate (98\%), starch solution, Triton X-100, Arabic gum, dinitrosalicylic acid (DNS), orlistat $\geq 98 \%$, quercetin $\geq 95 \%$, and acarbose $\geq 98 \%$ were acquired from Sigma Aldrich (Steinheim am Albuch, Germany). All chemicals and reagents utilized in the experiments were of analytical grade.

\subsection{Extraction of Anthocyanins from the Red Onion Skins}

The extraction of anthocyanins from the red onion skins was performed utilizing the UAE method, as described by Albishi et al. [62], with slight modifications. Therefore, $20 \mathrm{~g}$ of onion skins powder were mixed with $280 \mathrm{~mL}$ of aqueous ethanol $70 \%(v / v)$, acidified with glacial acetic acid (in a 6:1 ratio, \% (v/v)). The mixture was sonicated for $20 \mathrm{~min}$ at $25^{\circ} \mathrm{C}$ and $40 \mathrm{kHz}$ (MRC Scientific 193 Instruments, Holon, Israel), followed by centrifugation at 14,000 rpm and $4{ }^{\circ} \mathrm{C}$ for $5 \mathrm{~min}$ (Universal 320R cooling ultracentrifuge, Hettich, Tuttlingen, 
Germany). In order to increase the extraction yield, three successive extractions were performed. Afterward, the supernatants were collected and concentrated to dryness at $40^{\circ} \mathrm{C}$, under reduced pressure (AVC 2-18, Christ, Osterode, Germany).

\subsection{Extract Characterization}

The extract was spectrophotometrically described in terms of TAC, TPC, and antioxidant activity, as described by Stoica et al. [25]. Thus, $2 \mathrm{mg} / \mathrm{mL}$ of extract diluted in ultrapure water were used for the analysis. The TAC was measured utilizing the $\mathrm{pH}$-differential method and the results were expressed as mg cyanidin-3-O-glucoside equivalent (C3G)/g dry weight (DW). The TPC was analyzed using the Folin-Ciocâlteu method and the results were expressed as mg gallic acid equivalent (GAE)/g DW. The antioxidant activity of the UAE extract was assessed using the DPPH as free radical and the results were expressed as $\mathrm{mM}$ of Trolox equivalents (TE)/g DW. All phytochemicals were evaluated using a UV-VIS spectrophotometer with data analysis software (Libra S22, Biochrom, Cambridge, UK).

\subsection{Chromatographic Analysis of Anthocyanins}

The chromatographic profile of the anthocyanins extracted from red onion skins was achieved using a Thermo Finnigan Surveyor HPLC system coupled to a Diode-Array Detector and controlled by the Xcalibur software (Finnigan Surveyor LC, Thermo Scientific, Waltham, MA, USA). Over $4 \mathrm{~g}$ of extract, a volume of $4 \mathrm{~mL}$ of $10 \%$ formic acid solution, and a volume of $16 \mathrm{~mL}$ HPLC purity methanol were added to reach a total volume of $20 \mathrm{~mL}$, followed by homogenization. Prior to the chromatographic analysis, in order to exclude the majority of compounds that could interfere with the separation and identification of the anthocyanins from the red onion skins' extract, the sample was filtered through a C18 Sep-Pack cartridge (Cartridge-Waters, Milford, MA, USA). In order to separate and identify the red onion skins' compounds, a Synergi $4 \mathrm{u}$ Fusion-RP 80A $(150 \times 4.6 \mathrm{~mm}$, $4 \mu \mathrm{m})$ column was used, monitored at $520 \mathrm{~nm}$, at an oven temperature of $25^{\circ} \mathrm{C}$. The elution was performed using a flow rate of $1 \mathrm{~mL} / \mathrm{min}$ with a gradient of mobile phase A (methanol 100\%) and mobile phase B (water/formic acid 10\%). The following gradient was used for the samples: 0-20 $\mathrm{min}, 9-35 \%$ (A); $20-30 \mathrm{~min}, 35 \%$ (A); $30-40 \mathrm{~min}, 35-50 \%$ (A); and 40-55 $\mathrm{min}, 50-9 \%$ (A). The injection volume was $10 \mu \mathrm{L}$ for the samples. The anthocyanins from red onion skins extract were identified and quantified based on the retention time and by comparison to the available standards and data reported in the literature by Donner et al. [27], and Sharif et al. [63].

\subsection{Thermal Treatment}

For the heat treatment experiments, $2 \mathrm{~mL}$ of extract in ultrapure water $(2 \mathrm{mg} / \mathrm{mL})$ at a $\mathrm{pH}$ of 3.2, $(1 \mathrm{~N} \mathrm{HCl})$ were filed into screw-cap test glass tubes. The glass tubes were heated in the temperature range of $75-155^{\circ} \mathrm{C}$ for 15 to $60 \mathrm{~min}$, using a block heater (Stuart SBH200D, Stafford, UK). The parameters were picked taking into account the pasteurization and sterilization temperatures and times. After the thermal treatment, the samples were immediately cooled using an ice water bath to avoid further degradation. The experiment was performed in triplicate and the TACs and antioxidant activities of the thermally treated extracts were determined using the spectrophotometric methods described above.

\subsection{Kinetic Analysis}

The experimental data concerning the change in TAC and antioxidant activity over time were fitted to the first-order kinetics model (Equation (1)). The kinetic rate constant $(k)$ of thermal degradation, the half-life value $\left(t_{1 / 2}\right)$, decimal reduction time (D), $z$-values, and activation energy (Ea) were calculated as described by Peron et al. [12].

$$
\mathrm{C} / \mathrm{C}_{0}=\exp (-\mathrm{kt})
$$

where $C$ is the concentration of the parameter after time $t$ to be estimated (TAC or antioxidant activity), $\mathrm{C}_{0}$ signifies the concentration of the parameter in the initial condition (at 
time 0$),(\mathrm{mg} / \mathrm{g} \mathrm{DW})$, respectively, $\mathrm{t}$ is the thermal processing time, and $\mathrm{k}$ is the kinetic rate constant at temperature $\mathrm{T}$.

\subsection{Thermodynamic Parameters}

The thermodynamic parameters of TAC and antioxidant activity degradation, including the activation enthalpy $(\Delta \mathrm{H}, \mathrm{kJ} / \mathrm{mol})$, Gibbs free energy $(\Delta \mathrm{G}, \mathrm{kJ} / \mathrm{mol})$, and activation entropy $\left(\Delta \mathrm{S}, \mathrm{J} \cdot \mathrm{mol}^{-1} \cdot \mathrm{K}^{-1}\right)$ at each temperature were calculated according to Qiu et al. [40].

\subsection{Molecular Modeling Investigations on Anthocyanins Behavior at Thermal Treatment}

The thermal-dependent behavior of the main anthocyanin molecules identified in the red onion skins extract by means of HLPC was further checked by means of a molecular modeling approach. The molecular models of cyanidin 3-O-laminaribioside and cyanidin 3-O-(6"-malonyl-laminaribioside) were built, optimized, and equilibrated using the molecular modeling software HyperChem release 8.0 (Hypercube, Inc., Waterloo, ON, Canada). Two geometry optimization algorithms, namely Steepest descent and Conjugate gradient, were used in sequence to minimize the potential energy of the models until reaching a root means square gradient of $0.0001 \mathrm{kcal} /(\AA \cdot \mathrm{mol})$. Further molecular dynamics heating and equilibration steps at temperatures ranging from 75 to $155^{\circ} \mathrm{C}$, were carried out to simulate the thermal treatment and to check at a single molecule level any important changes occurring in the models.

\subsection{In Vitro Enzymes Activity Inhibition}

\subsection{1. $\alpha$-Amylase Inhibition Assay}

The $\alpha$-amylase inhibition by the red onion skins extract was measured according to Costamagna et al. [64], with slight modifications. Briefly, a volume of $100 \mu \mathrm{L}$ of extract solutions $(0.5,1$, and $5 \mu \mathrm{g} / \mathrm{mL}$ concentrations of extract diluted in ultrapure water) was added to $100 \mu \mathrm{L}$ of $\alpha$-amylase solution $(1 \mathrm{mg} / \mathrm{mL}$ in $0.1 \mathrm{M}$ PBS, $\mathrm{pH}=6.9)$. After $5 \mathrm{~min}$ of incubation at room temperature, $100 \mu \mathrm{L}$ of $1 \%(w / v)$ starch solution in distilled water was added into the reaction mixture and incubated for another $20 \mathrm{~min}$ at $37^{\circ} \mathrm{C}$. Further, $200 \mu \mathrm{L}$ of $0.04 \mathrm{M}$ DNS reagent was added into the reaction mixture, followed by heating at $100{ }^{\circ} \mathrm{C}$ for $5 \mathrm{~min}$ in a thermostatic water bath (Digibath-2 BAD 4, Raypa Trade, Barcelona, Spain). Finally, the samples were diluted with $2 \mathrm{~mL}$ of distilled water and the absorbance was measured at $540 \mathrm{~nm}$ with a UV-VIS spectrophotometer. Acarbose was used as a standard inhibitor. The results of $\alpha$-amylase inhibition activity were expressed in terms of IC50 value $(\mu \mathrm{g} / \mathrm{mL}$ of extract). The IC50 value $(\mu \mathrm{g} / \mathrm{mL})$ represents the extract concentration at which $50 \%$ of the enzyme activity is inhibited and was graphically plotted using the logarithmic concentrations of the extract versus the inhibition percentages of the enzyme.

\subsection{2. $\alpha$-Glucosidase Inhibition Assay}

The $\alpha$-glucosidase inhibitory activity of the red onion skins extract was also measured according to Costamagna et al. [64]. The reaction mixture contained $50 \mu \mathrm{L}$ of $\alpha$-glucosidase solution $(1 \mathrm{mg} / \mathrm{mL}$ in $0.1 \mathrm{M}$ PBS, $\mathrm{pH}=6.9)$ and $50 \mu \mathrm{L}$ extract solutions $(0.5,1$, and $5 \mu \mathrm{g} / \mathrm{mL})$. After the pre-incubation of the reaction mixture at room temperature for $5 \mathrm{~min}$, the enzyme reaction started by adding $50 \mu \mathrm{L}$ of $25 \mathrm{mM}$ p-nitrophenyl a-D-glucopyranoside and $1.6 \mathrm{~mL}$ of $0.1 \mathrm{M}$ PBS, $\mathrm{pH}=6.9$. The mixture was incubated for $15 \mathrm{~min}$ at $37^{\circ} \mathrm{C}$. Then, $800 \mu \mathrm{L}$ of $0.2 \mathrm{M}$ sodium carbonate was added. The absorbance was read at $405 \mathrm{~nm}$ with a UV-VIS spectrophotometer. Acarbose was used as a standard inhibitor. The inhibitory effect of the extract was expressed as IC50 $(\mu \mathrm{g} / \mathrm{mL})$ value.

\subsubsection{Lipase Inhibition Assay}

The lipase inhibitory effect of the extract was also assayed according to Costamagna et al. [64]. In brief, a volume of $50 \mu \mathrm{L}$ of pancreatin lipase solution $(1 \mathrm{mg} / \mathrm{mL}$ in $0.1 \mathrm{M}$ PBS, $\mathrm{pH}=8.0)$ was mixed with $50 \mu \mathrm{L}$ of red onion skins extract $(0.5$, 1 , and $5 \mu \mathrm{g} / \mathrm{mL}$ ) and kept at room temperature for $5 \mathrm{~min}$. Then, $50 \mu \mathrm{L}$ of the substrate, 
obtained with $0.01 \mathrm{M}$ p-nitrophenyl palmitate (in $0.1 \mathrm{M}$ PBS), $0.6 \%(w / v)$ Triton X-100, and $0.15 \%(w / v)$ Arabic gum was added and the solution was incubated at $37^{\circ} \mathrm{C}$ for $20 \mathrm{~min}$. More, the samples were diluted with $1 \mathrm{~mL}$ of $0.1 \mathrm{M}$ PBS at $\mathrm{pH}=8.0$. The absorbance was read at $400 \mathrm{~nm}$ with a UV-VIS spectrophotometer. Orlistat was used as the standard inhibitor. The inhibitory effect of the extract was expressed as IC50 $(\mu \mathrm{g} / \mathrm{mL})$ value.

\subsubsection{Lipoxygenase Inhibition Assay}

The biotest for the lipoxygenase (LOX) inhibition was performed according to Costamagna et al. [64], with slight modifications. Briefly, a volume of $50 \mu \mathrm{L}$ LOX solution $(1 \mathrm{mg} / \mathrm{mL}$ in $0.1 \mathrm{M}$ PBS, $\mathrm{pH}=9.0)$ was mixed with $50 \mu \mathrm{L}$ of extract solution $(0.5,1$, and $5 \mu \mathrm{g} / \mathrm{mL}$ ) and pre-incubated on room temperature for $5 \mathrm{~min}$. Then $50 \mu \mathrm{L}$ of $0.05 \mathrm{mM}$ linoleic acid dissolved in $0.1 \mathrm{M}$ PBS $(\mathrm{pH}=9.0)$ was added, and the mixture was incubated at $37{ }^{\circ} \mathrm{C}$ for $20 \mathrm{~min}$. Afterward, the samples were diluted with $2 \mathrm{~mL}$ of $0.1 \mathrm{M}$ PBS at $\mathrm{pH}=9.0$, and the absorbance was read at $234 \mathrm{~nm}$ with a UV-VIS spectrophotometer in quartz cuvettes. Quercetin was used as a standard inhibitor. The inhibitory effect of the extracts was expressed as the IC50 $(\mu \mathrm{g} / \mathrm{mL})$ value.

\subsection{In Silico Testing the Anthocyanins Binding to Enzymes}

Molecular docking tests were employed to identify the sites preferentially targeted by cyanidin 3-O-laminaribioside and cyanidin 3-O-( $6^{\prime \prime}$-malonyl-laminaribioside) when interacting with $\alpha$-amylase, $\alpha$-glucosidase, lipase, and LOX. After appropriate refinement, the three-dimensional models of the enzymes taken from the RCSB Protein Data Bank (PDB IDs 6Z8L [57], 5NN5 [58], 1N8S [65], 3O8Y [60] were used as receptors for the anthocyanins. The rigid docking procedure based on the molecular shape complementarity was done with the PatchDock algorithm [66]. The top three protein-ligand models scored based on the interaction energy values were further investigated for gathering insight on the potential mechanism responsible for enzymes inhibition.

\subsection{Statistical Analysis}

All experiments were performed in triplicate, and the results were expressed as mean values \pm standard deviation. The differences between the samples were assessed by the Tukey test with the one-way analysis of variance (ANOVA) method for the data that followed the normal distribution and equal variances conditions. The parameters of the kinetic models and the Arrhenius equation were estimated using linear regression. Mathematical models were selected by comparing correlations coefficients.

\section{Conclusions}

The red onion skins extract exhibited high total phenolics and anthocyanins contents and high antioxidant activity, which can increase its popularity as a promising source of bioactive compounds. The chromatographic profile showed the presence of eight main anthocyanins, with the major ones being cyanidin 3-O-laminaribioside and cyanidin 3-O( $6^{\prime \prime}$-malonyl-laminaribioside). The kinetics of the thermal degradation of total anthocyanins content and antioxidant activity were studied during heating at different temperatures $\left(75-155^{\circ} \mathrm{C}\right)$ and time $(0-60 \mathrm{~min})$. The results revealed that the degradation of both total anthocyanins content and antioxidant activity followed the first-order reaction kinetics, with the effect of temperature being adequately described by the Arrhenius model. The kinetic parameters revealed that the increase in temperature accelerated the degradation effect. Thus, higher stability of bioactive compounds was found at lower temperatures and shorter heating times during the thermal treatment. Moreover, the thermodynamic parameters confirmed the previous presumptions of irreversible and nonspontaneous reactions. The extract was also able to inhibit $\alpha$-glucosidase, $\alpha$-amylase, lipase, and lipoxygenase, enzymes associated with the metabolic syndrome and the inflammatory process.

The results presented in this study concerning the red onion skins anthocyanins provide the necessary information that enables the valorization of these by-products 
in multiple potential applications. These applications could refer to several industrial uses as nutraceuticals, food preserving agents, and pharmaceuticals. With extraordinary bioactivity, the phytochemicals present in the onion skins extract can be further investigated for the formulation of functional food ingredients.

Author Contributions: Conceptualization, F.S. and D.E.D.; methodology, F.S. and D.E.D.; software E.E. and I.A.; validation, N.S. and G.R.; formal analysis, F.S.; N.N.C. and D.E.D.; investigation, F.S., N.N.C., and D.E.D.; resources, G.E.B. and G.R.; data curation, F.S. and N.N.C.; writing—original draft preparation, F.S. and I.A.; writing—review and editing, G.R. and I.A.; visualization, G.E.B.; supervision, N.S.; project administration, G.E.B.; funding acquisition, G.E.B. and G.R. All authors have read and agreed to the published version of the manuscript.

Funding: This study was supported by a CNFIS-FDI-2021-0443 grant.

Institutional Review Board Statement: Not applicable.

Informed Consent Statement: Not applicable.

Data Availability Statement: The data that support the findings of this study are available from the corresponding author, G.R., upon reasonable request.

Acknowledgments: The Integrated Center for Research, Expertise, and Technological Transfer in the Food Industry is acknowledged for providing technical support.

Conflicts of Interest: The authors declare no conflict of interest.

\section{References}

1. Griffiths, G.; Trueman, L.; Crowther, T.; Thomas, B.; Smith, B. Onions-A Global Benefit to Health. Phytother. Res. 2002, 16, 603-615. [CrossRef] [PubMed]

2. Ramos, F.A.; Takaishi, Y.; Shirotori, M.; Kawaguchi, Y.; Tsuchiya, K.; Shibata, H.; Higuti, T.; Tadokoro, T.; Takeuchi, M. Antibacterial and Antioxidant Activities of Quercetin Oxidation Products from Yellow Onion (Allium Cepa) Skin. J. Agric. Food Chem. 2006, 54, 3551-3557. [CrossRef] [PubMed]

3. Gawlik-Dziki, U.; Kaszuba, K.; Piwowarczyk, K.; Świeca, M.; Dziki, D.; Czyz, J. Onion Skin—Raw Material for the Production of Supplement That Enhances the Health-Beneficial Properties of Wheat Bread. Food Res. Int. 2015, 73, 97-106. [CrossRef]

4. Ren, F.; Nian, Y.; Perussello, C.A. Effect of Storage, Food Processing and Novel Extraction Technologies on Onions Flavonoid Content: A Review. Food Res. Int. 2020, 132, 108953. [CrossRef] [PubMed]

5. Downes, K.; Chope, G.A.; Terry, L.A. Effect of Curing at Different Temperatures on Biochemical Composition of Onion (Allium Cepa L.) Skin from Three Freshly Cured and Cold Stored UK-Grown Onion Cultivars. Postharvest Biol. Technol. 2009, 54, 80-86. [CrossRef]

6. Kara, S..; Ercęlebi, E.A. Thermal Degradation Kinetics of Anthocyanins and Visual Colour of Urmu Mulberry (Morus Nigra L.). J. Food Eng. 2013, 116, 541-547. [CrossRef]

7. Yamaguchi, K.K.D.L.; Pereira, L.F.R.; Lamarão, C.V.; Lima, E.S.; Da Veiga-Junior, V.F. Amazon Acai: Chemistry and Biological Activities: A Review. Food Chem. 2015, 179, 137-151. [CrossRef]

8. Ogi, K.; Sumitani, H. Elucidation of an $\alpha$-Glucosidase Inhibitor from the Peel of Allium Cepa by Principal Component Analysis. Biosci. Biotechnol. Biochem. 2019, 83, 751-754. [CrossRef]

9. Jaiswal, N.; Rizvi, S.I. Amylase Inhibitory and Metal Chelating Effects of Different Layers of Onion (Allium Cepa L.) at Two Different Stages of Maturation in Vitro. Ann. Phytomedicine Int. J. 2017, VI, 45-50. [CrossRef]

10. Kim, H.Y. Effects of Onion (Allium Cepa) Skin Extract on Pancreatic Lipase and Body Weight-Related Parameters. Food Sci. Biotechnol. 2007, 16, 434-438.

11. Lesjak, M.; Beara, I.; Simin, N.; Pintać, D.; Majkić, T.; Bekvalac, K.; Orčić, D.; Mimica-Dukić, N. Antioxidant and Anti-Inflammatory Activities of Quercetin and Its Derivatives. J. Funct. Foods 2018, 40, 68-75. [CrossRef]

12. Peron, D.V.; Fraga, S.; Antelo, F. Thermal Degradation Kinetics of Anthocyanins Extracted from Juçara (Euterpe Edulis Martius) and "Italia" Grapes (Vitis Vinifera L.), and the Effect of Heating on the Antioxidant Capacity. Food Chem. 2017, 232, 836-840. [CrossRef] [PubMed]

13. Patras, A.; Brunton, N.P.; O’Donnell, C.; Tiwari, B.K. Effect of Thermal Processing on Anthocyanin Stability in Foods; Mechanisms and Kinetics of Degradation. Trends Food Sci. Technol. 2010, 21, 3-11. [CrossRef]

14. Burton-Freeman, B.; Sandhu, A.; Edirisinghe, I. Anthocyanins. In Nutraceuticals: Efficacy, Safety and Toxicity; Gupta, R.C., Ed.; Elsevier Science Publishing: Amsterdam, The Netherlands, 2016; pp. 489-500. [CrossRef]

15. Viera, V.B.; Piovesan, N.; Rodrigues, J.B.; Mello, R.d.O.; Prestes, R.C.; dos Santos, R.C.; Vaucher, R.d.A.; Hautrive, T.P.; Kubota, E.H. Extraction of Phenolic Compounds and Evaluation of the Antioxidant and Antimicrobial Capacity of Red Onion Skin (Allium Cepa L.). Int. Food Res. J. 2017, 24, 990-999. 
16. Slimestad, R.; Fossen, T.; Vågen, I.M. Onions: A Source of Unique Dietary Flavonoids. J. Agric. Food Chem. 2007, 55, 10067-10080. [CrossRef]

17. Metrani, R.; Singh, J.; Acharya, P.; Jayaprakasha, G.K.; Patil, B.S. Comparative Metabolomics Profiling of Polyphenols, Nutrients and Antioxidant Activities of Two Red Onion (Allium Cepa L.) Cultivars. Plants 2020, 9, 1077. [CrossRef]

18. Ali, O.-H.A.A.; Al-Sayed, H.M.A.; Yasin, N.M.N.; Afifi, E.A.A. Effectof Different Extraction Methodson Stablity of Anthocyanins Extracted from Red Onion Peels (Allium Cepa) and Its Uses as Food Colorants. Bull. Natl. Nutr. Inst. Arab Repub. Egypt 2016, $47,197$.

19. Katsampa, P.; Valsamedou, E.; Grigorakis, S.; Makris, D.P. A Green Ultrasound-Assisted Extraction Process for the Recovery of Antioxidant Polyphenols and Pigments from Onion Solid Wastes Using Box-Behnken Experimental Design and Kinetics. Ind. Crops Prod. 2015, 77, 535-543. [CrossRef]

20. Makris, D.P. Optimisation of Anthocyanin Recovery from Onion (Allium Cepa) Solid Wastes Using Response Surface Methodology. J. Food Technol. 2010, 8, 183-186.

21. Škerget, M.; Majheniě, L.; Bezjak, M.; Knez, Ž. Antioxidant, Radical Scavenging and Antimicrobial Activities of Red Onion (Allium Cepa L.) Skin and Edible Part Extracts. Chem. Biochem. Eng. Q. 2009, 23, 435-444.

22. Yang, S.J.; Paudel, P.; Shrestha, S.; Seong, S.H.; Jung, H.A.; Choi, J.S. In Vitro Protein Tyrosine Phosphatase 1B Inhibition and Antioxidant Property of Different Onion Peel Cultivars: A Comparative Study. Food Sci. Nutr. 2019, 7, 205-215. [CrossRef]

23. Lee, K.A.; Kim, K.T.; Kim, H.J.; Chung, M.S.; Chang, P.S.; Park, H.; Pai, H.D. Antioxidant Activities of Onion (Allium Cepa L.) Peel Extracts Produced by Ethanol, Hot Water, and Subcritical Water Extraction. Food Sci. Biotechnol. 2014, 23, 615-621. [CrossRef]

24. Prokopov, T.; Slavov, A.; Petkova, N.; Yanakieva, V.; Bozadzhiev, B.; Taneva, D. Study of Onion Processing Waste Powder for Potential Use in Food Sector. Acta Aliment. 2018, 47, 181-188. [CrossRef]

25. Stoica, F.; Râpeanu, G.; Nistor, O.V.; Enachi, E.; Stănciuc, N.; Mureșan, C.B.G.E. Recovery of Bioactive Compounds from Red Onion Skins Using Conventional Solvent Extraction and Microwave Assisted Extraction. Ann. Univ. Dunarea De Jos Galati Fascicle VI-Food Technol. 2020, 44, 104-126. [CrossRef]

26. Pérez-Gregorio, R.M.; García-Falcón, M.S.; Simal-Gándara, J.; Rodrigues, A.S.; Almeida, D.P.F. Identification and Quantification of Flavonoids in Traditional Cultivars of Red and White Onions at Harvest. J. Food Compos. Anal. 2010, 23, 592-598. [CrossRef]

27. Donner, H.; Gao, L.; Mazza, G. Separation and Characterization of Simple and Malonylated Anthocyanins in Red Onions, Allium Cepa L. Food Res. Int. 1997, 30, 637-643. [CrossRef]

28. Turturică, M.; Stănciuc, N.; Bahrim, G.; Râpeanu, G. Effect of Thermal Treatment on Phenolic Compounds from Plum (Prunus Domestica) Extracts-A Kinetic Study. J. Food Eng. 2016, 171, 200-207. [CrossRef]

29. Turturică, M.; Stănciuc, N.; Bahrim, G.; Râpeanu, G. Investigations on Sweet Cherry Phenolic Degradation During Thermal Treatment Based on Fluorescence Spectroscopy and Inactivation Kinetics. Food Bioprocess Technol. 2016, 9, 1706-1715. [CrossRef]

30. Oancea, A.M.; Turturică, M.; Bahrim, G.; Râpeanu, G.; Stănciuc, N. Phytochemicals and Antioxidant Activity Degradation Kinetics during Thermal Treatments of Sour Cherry Extract. LWT-Food Sci. Technol. 2017, 82, 139-146. [CrossRef]

31. Sadilova, E.; Stintzing, F.C.; Carle, R. Thermal Degradation of Acylated and Nonacylated Anthocyanins. J. Food Sci. 2006, 71, C504-C512. [CrossRef]

32. Zhang, L.; Zhou, J.; Liu, H.; Khan, M.A.; Huang, K.; Gu, Z. Compositions of Anthocyanins in Blackberry Juice and Their Thermal Degradation in Relation to Antioxidant Activity. Eur. Food Res. Technol. 2012, 235, 637-645. [CrossRef]

33. Benítez, V.; Mollá, E.; Martín-Cabrejas, M.A.; Aguilera, Y.; López-Andréu, F.J.; Cools, K.; Terry, L.A.; Esteban, R.M. Characterization of Industrial Onion Wastes (Allium Cepa L.): Dietary Fibre and Bioactive Compounds. Plant Foods Hum. Nutr. 2011, 66, 48-57. [CrossRef]

34. Jackman, R.L.; Smith, J.L. Anthocyanins and Betalains BT-Natural Food Colorants. Nat. Food Color. 1996, $244-309$.

35. Slavin, M.; Lu, Y.; Kaplan, N.; Yu, L. Effects of Baking on Cyanidin-3-Glucoside Content and Antioxidant Properties of Black and Yellow Soybean Crackers. Food Chem. 2013, 141, 1166-1174. [CrossRef] [PubMed]

36. Sui, X.; Zhou, W. Monte Carlo Modelling of Non-Isothermal Degradation of Two Cyanidin-Based Anthocyanins in Aqueous System at High Temperatures and Its Impact on Antioxidant Capacities. Food Chem. 2014, 148, 342-350. [CrossRef] [PubMed]

37. Al-Qadri, F. Kinetics Study and Thermal Stability of Red Onion Skin and It's Use as Alternative Colorants in Food and Textiles. Int. Adv. Res. J. Sci. Eng. Technol. 2018, 5, 52-58. [CrossRef]

38. Holdsworth, S.D. Optimisation of Thermal Processing-A Review. J. Food Eng. 1985, 4, 89-116. [CrossRef]

39. Nayak, B.; Berrios, J.D.J.; Powers, J.R.; Tang, J. Thermal Degradation of Anthocyanins from Purple Potato (Cv. Purple Majesty) and Impact on Antioxidant Capacity. J. Agric. Food Chem. 2011, 59, 11040-11049. [CrossRef]

40. Qiu, G.; Wang, D.; Song, X.; Deng, Y.; Zhao, Y. Degradation Kinetics and Antioxidant Capacity of Anthocyanins in AirImpingement Jet Dried Purple Potato Slices. Food Res. Int. 2018, 105, 121-128. [CrossRef]

41. Sarpong, F.; Yu, X.; Zhou, C.; Amenorfe, L.P.; Bai, J.; Wu, B.; Ma, H. The Kinetics and Thermodynamics Study of Bioactive Compounds and Antioxidant Degradation of Dried Banana (Musa Ssp.) Slices Using Controlled Humidity Convective Air Drying. J. Food Meas. Charact. 2018, 12, 1935-1946. [CrossRef]

42. Vikram, V.B.; Ramesh, M.N.; Prapulla, S.G. Thermal Degradation Kinetics of Nutrients in Orange Juice Heated by Electromagnetic and Conventional Methods. J. Food Eng. 2005, 69, 31-40. [CrossRef]

43. Al-Zubaidy, M.M.I.; Khalil, R.A. Kinetic and Prediction Studies of Ascorbic Acid Degradation in Normal and Concentrate Local Lemon Juice during Storage. Food Chem. 2007, 101, 254-259. [CrossRef] 
44. Zahir, E.; Saleem, T.; Siddiqui, H.; Naz, S.; Shahid, S. Kinetic and Thermodynamic Studies of Antioxidant and Antimicrobial Activities of Essential Oil of Lavendula Steochs. J. Basic Appl. Sci. 2015, 11, 217-222. [CrossRef]

45. Liu, K.; Luo, M.; Wei, S. The Bioprotective Effects of Polyphenols on Metabolic Syndrome against Oxidative Stress: Evidences and Perspectives. Oxidative Med. Cell. Longev. 2019, 2019, 6713194. [CrossRef] [PubMed]

46. Galavi, A.; Hosseinzadeh, H.; Razavi, B.M. The Effects of Allium Cepa L. (Onion) and Its Active Constituents on Metabolic Syndrome: A Review. Iran. J. Basic Med. Sci. 2020, 24, 3-16. [CrossRef]

47. Filippatos, T.D.; Derdemezis, C.S.; Gazi, I.F.; Nakou, E.S.; Mikhailidis, D.P.; Elisaf, M.S. Orlistat-Associated Adverse Effects and Drug Interactions: A Critical Review. Drug Saf. 2008, 31, 53-65. [CrossRef]

48. Leroux-Stewart, J.; Rabasa-Lhoret, R.; Chiasson, J.-L. $\alpha$-Glucosidase Inhibitors. In International Text book of Diabetes Mellitus, 4 th ed.; De Fronzo, R.A., Ferrannini, E., Zimmet, P., Alberti, G., Eds.; John Wiley \& Sons Publishing: Hoboken, NJ, USA, 2015; Volume 3, pp. 673-685. [CrossRef]

49. Nile, A.; Gansukh, E.; Park, G.S.; Kim, D.H.; Hariram Nile, S. Novel Insights on the Multi-Functional Properties of Flavonol Glucosides from Red Onion (Allium Cepa L.) Solid Waste-In Vitro and in Silico Approach. Food Chem. 2021, 335, 127650. [CrossRef]

50. Nile, A.; Nile, S.H.; Kim, D.H.; Keum, Y.S.; Seok, P.G.; Sharma, K. Valorization of Onion Solid Waste and Their Flavonols for Assessment of Cytotoxicity, Enzyme Inhibitory and Antioxidant Activities. Food Chem. Toxicol. 2018, 119, 281-289. [CrossRef]

51. Oboh, G.; Ademiluyi, A.O.; Agunloye, O.M.; Ademosun, A.O.; Ogunsakin, B.G. Inhibitory Effect of Garlic, Purple Onion, and White Onion on Key Enzymes Linked with Type 2 Diabetes and Hypertension. J. Diet. Suppl. 2019, 16, 105-118. [CrossRef]

52. Kim, S.H.; Jo, S.H.; Kwon, Y.I.; Hwang, J.K. Effects of Onion (Allium Cepa L.) Extract Administration on Intestinal $\alpha$-Glucosidases Activities and Spikes in Postprandial Blood Glucose Levels in SD Rats Model. Int. J. Mol. Sci. 2011, 12, 3757-3769. [CrossRef]

53. Nikavar, B.; Yousefian, N. Inhibitory Effects of Six Allium Species on Alpha-Amylase Enzyme Activity. Iran. J. Pharm. Res. 2009, 8, 53-57.

54. Bisen, S.P.; Emerald, M. Nutritional and Therapeutic Potential of Garlic and Onion (Allium Sp.). Curr. Nutr. Food Sci. 2016, 12, 190-199. [CrossRef]

55. Hossain, M.K.; Dayem, A.A.; Han, J.; Yin, Y.; Kim, K.; Saha, S.K.; Yang, G.M.; Choi, H.Y.; Cho, S.G. Molecular Mechanisms of the Anti-Obesity and Anti-Diabetic Properties of Flavonoids. Int. J. Mol. Sci. 2016, 17, 569. [CrossRef]

56. Trisat, K.; Wong-on, M.; Lapphanichayakool, P.; Tiyaboonchai, W.; Limpeanchob, N. Vegetable Juices and Fibers Reduce Lipid Digestion or Absorption by Inhibiting Pancreatic Lipase, Cholesterol Solubility and Bile Acid Binding. Int. J. Veg. Sci. 2017, 23, 260-269. [CrossRef]

57. Axer, A.; Jumde, R.P.; Adam, S.; Faust, A.; Schäfers, M.; Fobker, M.; Koehnke, J.; Hirsch, A.K.H.; Gilmour, R. Enhancing Glycan Stabilityviasite-Selective Fluorination: Modulating Substrate Orientation by Molecular Design. Chem. Sci. 2021, 12, 1286-1294. [CrossRef]

58. Roig-Zamboni, V.; Cobucci-Ponzano, B.; Iacono, R.; Ferrara, M.C.; Germany, S.; Bourne, Y.; Parenti, G.; Moracci, M.; Sulzenbacher, G. Structure of Human Lysosomal Acid $\alpha$-Glucosidase-A Guide for the Treatment of Pompe Disease. Nat. Commun. 2017, 8, 1111. [CrossRef] [PubMed]

59. Hadvary, P.; Sidler, W.; Meister, W.; Vetter, W.; Wolfer, H. The Lipase Inhibitor Tetrahydrolipstatin Binds Covalently to the Putative Active Site Serine of Pancreatic Lipase. J. Biol. Chem. 1991, 266, 2021-2027. [CrossRef]

60. Gilbert, N.C.; Bartlett, S.G.; Waight, M.T.; Neau, D.B.; Boeglin, W.E.; Brash, A.R.; Newcomer, M.E. The Structure of Human 5-Lipoxygenase. Science 2011, 331, 217-219. [CrossRef]

61. Humphrey, W.; Dalke, A.; Schulten, K. VMD: Visual Molecular Dynamics. J. Mol. Graph. 1996, 14, 33-38. [CrossRef]

62. Albishi, T.; John, J.A.; Al-Khalifa, A.S.; Shahidi, F. Antioxidative Phenolic Constituents of Skins of Onion Varieties and Their Activities. J. Funct. Foods 2013, 5, 1191-1203. [CrossRef]

63. Sharif, A.; Saim, N.; Jasmani, H.; Ahmad, W.Y.W. Effects of Solvent and Temperature on the Extraction of Colorant from Onion (Allium Cepa) Skin Using Pressurized Liquid Extraction. Asian J. Appl. Sci. 2010, 3, 262-268. [CrossRef]

64. Costamagna, M.S.; Zampini, I.C.; Alberto, M.R.; Cuello, S.; Torres, S.; Pérez, J.; Quispe, C.; Schmeda-Hirschmann, G.; Isla, M.I. Polyphenols Rich Fraction from Geoffroea Decorticans Fruits Flour Affects Key Enzymes Involved in Metabolic Syndrome, Oxidative Stress and Inflammatory Process. Food Chem. 2016, 190, 392-402. [CrossRef]

65. van Tilbeurgh, H.; Sarda, L.; Verger, R.; Cambillau, C. Structure of the Pancreatic Lipase-Procolipase Complex. Nature 1992, 359, 159-162. [CrossRef] [PubMed]

66. Schneidman-Duhovny, D.; Inbar, Y.; Nussinov, R.; Wolfson, H.J. PatchDock and SymmDock: Servers for Rigid and Symmetric Docking. Nucleic Acids Res. 2005, 33, 363-367. [CrossRef] [PubMed] 